\title{
Biogeochemical fluxes in landscapes
}

\author{
Ülo Mander · Xiuzhen Li • Martin J. Wassen
}

Received: 4 March 2013/Accepted: 6 March 2013/Published online: 17 March 2013

(C) Springer Science+Business Media Dordrecht 2013

The relationship between landscape pattern and material cycling in landscapes and its functional units-watersheds (catchments) - is a classic area in landscape research (Bormann and Likens 1979; Peterjohn and Correll 1984; Wassen and Barendregt 1992, Arheimer and Brand 2000; Pionke et al. 2000; Burt and Pinay 2005; Laudon et al. 2007; Naiman and Decamps 2007; Pärn et al. 2012). Together with (meta)population dynamics in mosaic landscapes, land-use dynamics and landscape structure analysis,

Ü. Mander $(\bowtie)$

Department of Geography, Institute of Ecology and Earth Sciences, University of Tartu, 46 Vanemuise Street, 51014 Tartu, Estonia

e-mail: ulo.mander@ut.ee

\section{Ü. Mander}

Hydrosystems and Bioprocesses Research Unit, National Research Institute of Science and Technology for Environment and Agriculture (Irstea), 1 rue Pierre-Gilles de Gennes CS 10030, 92761 Antony cedex, France

\section{Li}

State Key Laboratory of Estuarine and Coastal Research, East China Normal University, Shanghai 200062, China

\section{J. Wassen}

Environmental Sciences, Faculty of Geosciences, Copernicus Institute of Sustainable Development, Utrecht University, PO Box 80115, 3508, TC, Utrecht, The Netherlands these fields cover the majority of all investigations in landscape ecology (Wu and Hobbs 2002; Li and Mander 2009). Of biogeochemical fluxes, cycles of carbon and nitrogen-those that are most altered by human activities (Vitousek et al. 1997)—as well as their hotspots in landscapes, have been under examination (Peterson et al. 2001; McClain et al. 2003; Seitzinger et al. 2006). Likewise, phosphorus cycling, which is significant for the ecological status of freshwater bodies and terrestrial ecosystems, is among the most frequently studied material cycles in landscapes and catchments (Sharpley et al. 1994; Carpenter et al. 1998).

The alteration of biogeochemical cycles influences all landscape processes, including those related to biodiversity issues (Tilman et al. 1996; Wassen et al. 2005; Naeem et al. 2012). In recent decades, due to growing interest in phenomena caused by global warming, the quantity of studies on greenhouse gas emissions at watershed scale (Vilain et al. 2012) and local to regional landscape scale (Le Mer and Roger 2001; Sozanska et al. 2002; Lilly et al. 2003, Sommer et al. 2004; Mander et al. 2010; Wolf et al. 2010; Nol et al. 2012; Schelde et al. 2012) has increased significantly.

To help improve our understanding of "landscape biogeochemistry," we organized a symposium entitled "Biogeochemical Fluxes in Landscapes" during the 8th World Congress on Landscape Ecology in Beijing in August 2011. This special issue is based on the Beijing symposium. 


\section{About this special issue}

The special issue consists of eight research articles. In the first one, Mitsch et al. (2013) consider the role of wetlands in climate warming. Wetland ecosystems provide an optimum natural environment for the sequestration and long-term storage of carbon dioxide $\left(\mathrm{CO}_{2}\right)$ from the atmosphere, yet are natural sources of greenhouse gas emissions, especially methane $\left(\mathrm{CH}_{4}\right)$. It is shown that most wetlands, do not have 25 times more $\mathrm{CO}_{2}$ sequestration than $\mathrm{CH}_{4}$ emissions when carbon (C) sequestration is compared to methane emissions; therefore, most wetlands would be considered by many landscape managers and non specialists to be sources of climate warming or net radiative forcing. The dynamic modeling of carbon flux results from 21 detailed wetland studies has shown that $\mathrm{CH}_{4}$ emissions become unimportant within 300 years compared to $\mathrm{C}$ sequestration in wetlands. Within that time frame or less, most wetlands become both net carbon and radiative sinks. It has also been estimated that the world's wetlands, despite being only about 5-8 \% of the terrestrial landscape, may currently act as net carbon sinks of about $830 \mathrm{Tg} /$ year of carbon, with an average of $118 \mathrm{gC} / \mathrm{m}^{2} /$ year of net carbon retention. Most of that carbon retention occurs in tropical/subtropical wetlands. The authors demonstrate that almost all wetlands are net radiative sinks when balancing $\mathrm{C}$ sequestration and $\mathrm{CH}_{4}$ emissions, and conclude that wetlands can be created and restored to provide $\mathrm{C}$ sequestration and other ecosystem services without great concern for creating net radiative sources in the climate due to $\mathrm{CH}_{4}$ emissions.

In their perspective paper, Wassen et al. (2013) integrate a number of recent research findings into known relationships that together reveal interactions between different elemental cycles and the water cycle through vegetation, and could potentially have unexpected effects on landscapes and larger-scale (continental, global) systems. These interactions include processes on very distinct temporal and spatial scales in which plants and vegetation play a key role. This implies that vegetation is not only affected by global change but also drives global change by influencing fluxes of these elements and the link between them. The authors propose that it is necessary to account for plant processes and how these interfere with elemental cycles in order to achieve a better understanding of the effects of changes in land cover and land use for biogeochemical and biogeophysical fluxes. Directions for further research to fill the current knowledge gaps are suggested.

Haas et al. (2013) present a new model system for the simulation of biosphere-atmosphere-hydrosphere exchange processes at landscape scale. The new framework LandscapeDNDC-partly based on the biogeochemical site-scale model DNDC-facilitates scaling of ecosystem processes from the site to regional simulation domains and inherits a series of new features with regard to process descriptions, model structure and data functionality. LandscapeDNDC incorporates different vegetation types and management systems for the simulation of $\mathrm{C}$, nitrogen (N) and water-related biosphere-atmosphere-hydrosphere fluxes in forest, arable and grassland ecosystems and allows the dynamic simulation of land use changes. The modeling concept divides ecosystems into six substrates and provides alternative modules for those substrates. The model can be applied on the site scale and also for three-dimensional regional simulations. For regional applications LandscapeDNDC integrates all grid cells synchronously forward in time. This allows for easy coupling to other spatially-distributed models (e.g. for hydrology or atmospheric chemistry) and efficient two-way exchange of states. Two of these are presented. The first sample application demonstrated that calculated nitrous oxide $\left(\mathrm{N}_{2} \mathrm{O}\right)$ emissions for the State of Saxony (Germany) with LandscapeDNDC (2693 t N $2 \mathrm{O}-\mathrm{N} /$ year) were 2.4 times higher than those calculated according to the IPCC Tier I methodology, and $28 \%$ higher than the results of the German National Inventory Report (IPCC Tier II). The second example illustrates the capabilities of LandscapeDNDC for the building of a fully-coupled three-dimensional model system on the landscape scale. The model combines biogeochemical and plant growth calculations into a hydrological transport model and demonstrates $\mathrm{N}$ transport along a virtual hill slope and the associated formation of indirect $\mathrm{N}_{2} \mathrm{O}$ emissions.

Hansen et al. (2013) studied greenhouse gas fluxes in a free-air humidity manipulation (FAHM) facility established in 2006 in Estonia in order to investigate the effect of humidity on the performance of forest ecosystems. The trial is located on former arable land and offers the opportunity to change relative air humidity through controlled artificial misting and drying. Measurements were carried out once a month 
from July 2009 to October 2010 on three humidification plots and in three control plots using closed chamber and gas-chromatograph techniques. The dry summer in 2010 interacted stronger with the humidification than the rainy vegetation period in 2009. In this summer the $\mathrm{CO}_{2}$ flux decreased when the air moisture was higher than in the control plots. The soil (Endogleyic Planosol) always acted as a sink for methane, although less $\mathrm{CH}_{4}$ was oxidized in the soil with increased humidity. There was a smaller $\mathrm{N}_{2} \mathrm{O}$ flux during the increased humidity period. As expected, $\mathrm{CO}_{2}$ emission and $\mathrm{CH}_{4}$ consumption demonstrated strong positive correlations with soil temperature.

Gall et al. (2013) examined time-series of hydrological and biogeochemical responses of managed catchments in terms of the degree of stochastic, nonlinear filtering of hydro-climatic and anthropogenic drivers. Two metrics of catchment filtering were applied to three case studies to examine the degree of synchronicity between catchment signals (e.g. drivers and responses). The first filtering metric evaluates the relative inequality of the two signals, whereas the second metric is based on spectral analysis and evaluates the relative memory of the two signals. These metrics were used to evaluate the filtering of precipitation inputs to discharge outputs from four stations in different moisture regimes and to identify the human impact on catchment hydrology. The analyses suggest that an increasing human impact on landscapes (1) causes hydrological and biogeochemical processes to exhibit increasing functional homogeneity; (2) contributes to shifts in nitrate $\left(\mathrm{NO}_{3}{ }^{-}\right)$ memory between catchment drivers and responses; and (3) decreases the temporal inequality of nutrient export dynamics.

The paper by Billy et al. (2013) aims to highlight the role of hydrological and biogeochemical retention processes in the determination of nitrate concentration in an artificially-drained agricultural watershed. The Orgeval watershed (East part of Paris, France, belonging to a long term environmental observatory network) is divided into several nested sub-basins from 1 to $100 \mathrm{~km}^{2}$. A two-level monitoring activity was carried out during the 2007/2008 hydrological year: permanently at six monitoring stations $\left(\mathrm{NO}_{3}{ }^{-}\right.$concentration and discharge) and 20 points over the watershed (discharge, chloride, nitrate, sulphate, calcium concentration and $\mathrm{N}$ isotopic composition) for three different dates (October, January and April). The particular situation of artificial drainage generates modified water transfer and thus $\mathrm{NO}_{3}{ }^{-}$transformation processes during the wet drainage season in winter. Dilution processes by forested areas seem to be a prime factor determining global water quality. A threshold of $34 \%$ of forest cover allows the maintenance of $\mathrm{NO}_{3}{ }^{-}$concentration below the drinking water limit $\left(11.3 \mathrm{mg} \mathrm{N}^{-1}\right)$. The comparative isotopic and chemical analyses showed that retention processes also influence water quality during the dry season.

The study by Wang et al. (2013) utilizes two sites (dry versus wet) from a megatransect in southern Africa encompassing locations with similar soil substrates but different rainfall and vegetation, in order to explore the effects of soil moisture and vegetation distribution on ecosystem-scale patterns of soil $\delta{ }^{15} \mathrm{~N}$. A 300-m-long transect was set up at each site, and surface soil samples were randomly collected for analyses of $\delta{ }^{15} \mathrm{~N}, \% \mathrm{~N}$, and $\mathrm{NO}_{3}{ }^{-}$content. At each soil sampling location the presence of grasses, woody plants, Acacia species (a potential $\mathrm{N}$ fixer) and soil moisture levels were recorded. The results suggest that vegetation distribution, directly affects, and water availability indirectly affects the spatial patterns of soil $\delta{ }^{15} \mathrm{~N}$ through their effects on woody plant and grass distributions.

Li et al. (2013) used the "space for time substitution" method to test the impact of time on changes in land use intensity after reclamation in the Yangtze Estuary area and found that human dominated land uses increased quickly within the first 35 years after reclamation and then slowed down. Soil salinity was relatively higher in aquaculture ponds than in areas with other types of land cover due to the use of saline ground water and the influence of the sea. Soil organic matter, available $\mathrm{P}$ and $\mathrm{NO}_{3}{ }^{-}-\mathrm{N}$ were relatively high in agricultural fields, and the variability of $\mathrm{NO}_{3}{ }^{-}-\mathrm{N}$ was high. The variations of all soil properties in the built-up zone were much higher than those in the other land use groups. The results will provide a sound basis for future land use planning of newly reclaimed land and for further studies on the ecological consequences of salt marsh reclamation.

This special issue contributes to one of the top research priorities in landscape ecology (Wu and Hobbs 2002; Wu 2013): ecological flows in landscape mosaics. It is not enough to address every aspect of this subject in one issue. Therefore, more efforts are 
needed to reveal the multiple relationships between different ecological processes and landscape patterns.

\section{Concluding remarks}

Terrestrial ecosystems play a central role in biogeochemical fluxes and the net outcome of greenhouse gas fluxes from land to the atmosphere and vice versa. Biogeochemical fluxes determined in landscape elements can be scaled up to contributions to regional, continental and global balances of elements. They also link (sub-) ecosystems, such as above- and below ground subsystems. However, such subsystems have rarely been tested on larger scales in the field, so that it is very difficult to extrapolate a link between small- and large-scale processes. It is hoped that experimental land restoration programs will provide opportunities to determine fluxes of greenhouse gasses and analyze whether interactions between various cycles occur and what the exact role of terrestrial vegetation is in these feedbacks under different circumstances.

Undoubtedly, future effects of human activities on land use, atmospheric $\mathrm{CO}_{2}$ concentrations, temperature, nitrogen deposition, and other processes will have strong impacts on ecosystem functioning and ecosystem services, but there has been too much emphasis on the unidirectional cause-effect chain from landscape to fluxes, while feedbacks have been largely ignored and the up-scaling of plant processes to vegetation and how this will impact on the interaction between different fluxes still needs to be explored. Unraveling these interactions under the current scale of change is an enormous challenge to the scientific community in order to better understand the consequences for carbon, water and nitrogen cycling, global warming and climate.

This special issue provides only eight out of twenty presentations and do not reflect the many discussions we had. We hope that this special issue still will contribute to a better understanding of the complexity and diversity of biogeochemical fluxes in landscapes, the processes ruling them and that we succeeded in highlighting the need of detailed experimental measuring programs and bringing together different approaches into landscape ecology, thereby encouraging new research across the various disciplines and landscape scales.
Acknowledgments We acknowledge the financial help by Estonian Science Foundation Grant No. 9624 and Target Funding Projects No. SF0180127s08 and IUT2-16 of the Ministry of Education and Science of Estonia, and the 111 Project (B08022), Ministry of Education, China. We would like to thank all reviewers for their critical remarks which have substantially improved the quality of the papers.

\section{References}

Arheimer B, Brand M (2000) Watershed modelling of non-point nitrogen from arable land to the Swedish coast in 1985 and 1994. Ecol Eng 14:389-404

Billy C, Birgand F, Ansart P, Peschard J, Sebilo M, Tournebize J (2013) Factors controlling nitrate concentrations in surface waters of an agricultural and artificially drained watershed. Landscape Ecol. doi:10.1007/s10980-013-9872-2

Bormann DB, Likens GE (1979) Pattern and processes in a forested ecosystem. Springer, New York, p 253

Burt TP, Pinay G (2005) Linking biogeochemistry and hydrology in complex landscapes. Prog Phys Geog 29:297-316

Carpenter SR, Caraco NF, Correll DL, Howarth RW, Sharpley AN, Smith VH (1998) Nonpoint pollution of surface waters with phosphorus and nitrogen. Ecol Appl 8:559-568

Gall HE, Park J, Harman C, Jawitz JW, Rao PSC (2013) Landscape filtering of hydrologic and biogeochemical responses in managed catchments. Landscape Ecol. doi: 10.1007/s10980-012-9829-x

Haas E, Klatt S, Fröhlich A, Kraft P, Werner C, Kiese R, Grote R, Breuer L, Butterbach-Bahl K (2013) LandscapeDNDC: a process model for simulation of biosphere-atmospherehydrosphere exchange processes at site and regional scale. Landscape Ecol. doi:10.1007/s10980-012-9772-x

Hansen R, Mander Ü, Soosaar K, Maddison M, Lõhmus K, Kupper P, Kanal A, Sõber J (2013) Greenhouse gas fluxes in an open air humidity manipulation experiment. Landscape Ecol. doi:10.1007/s10980-012-9775-7

Laudon H, Sjöblom V, Buffam I, Seibert J, Morth M (2007) The role of catchment scale and landscape characteristics for runoff generation of boreal streams. J Hydrol 344:198-209

Le Mer J, Roger P (2001) Production, oxidation, emission and consumption of methane by soils: review. Eur J Soil Biol 37:25-50

Li X, Mander Ü (2009) Future options in landscape ecology: development and research. Prog Phys Geog 33:31-48

Li XZ, Sun YG, Mander Ü, He YL (2013) Effects of land use intensity on soil nutrient distribution after reclamation in an estuary landscape. Landscape Ecol. doi:10.1007/s10980012-9796-2

Lilly A, Ball BC, McTaggart IP, Horne PL (2003) Spatial and temporal scaling of nitrous oxide emissions from the field to the regional scale in Scotland. Nutr Cycl Agroecosys 66:241-257

McClain ME, Boyer EW, Dent CL, Gergel SE, Grimm NB, Groffman PM, Hart SC, Harvey JW, Johnston CA, Mayorga E, McDowell WH, Pinay G (2003) Biogeochemical hot spots and hot moments at the interface of terrestrial and aquatic ecosystems. Ecosystems 6:301-312 
Mitsch WJ, Bernal B, Nahlik AM, Mander Ü, Zhang L, Anderson CJ, Jørgensen SE, Brix H (2013) Wetlands, carbon, and climate change. Landscape Ecol. doi:10.1007/ s10980-012-9758-8

Naeem S, Duffy JE, Zavaleta ER (2012) The functions of biological diversity in an age of extinction. Science 336:14011406

Naiman RJ, Decamps H (2007) The ecology of interface: riparian zones. Annu Rev Ecol Syst 28:621-658

Nol L, Verburg PH, Moors EJ (2012) Trends in future $\mathrm{N}_{2} \mathrm{O}$ emissions due to land use change. J Environ Manage 94:78-90

Pärn J, Pinay G, Mander Ü (2012) Indicators of nutrients transport from agricultural catchments under temperate climate: a review. Ecol Indicators 22:4-15

Peterjohn WT, Correll DL (1984) Nutrient dynamics in an agricultural watershed: observations on the role of a riparian forest. Ecology 65:1466-1475

Peterson BJ, Wollheim WM, Mulholland PJ, Webster JR, Meyer JL, Tank JL, Marti E, Bowden WB, Valett HM, Hershey AE, McDowell WH, Dodds WK, Hamilton SK, Gregory S, Morrall DD (2001) Control of nitrogen export from watersheds by headwater streams. Science 292:86-90

Pionke HB, Gburek WJ, Sharpley AN (2000) Critical source area controls on water quality in an agricultural watershed located in the Chesapeake Basin. Ecol Eng 14:325-335

Schelde K, Cellier P, Bertolini T, Dalgaard T, Weidinger T, Theobald MR, Olesen JE (2012) Spatial and temporal variability of nitrous oxide emissions in a mixed farming landscape of Denmark. Biogeosciences 9:2989-3002

Seitzinger S, Harrison JA, Bohlke JK (2006) Denitrification across landscapes and waterscapes: a synthesis. Ecol Appl 16:2064-2090

Sharpley AN, Chapra SC, Wedepohl R, Sims JT, Daniel TC, Reddy KR (1994) Managing agricultural phosphorus for protection of surface waters - Issues and options. J Environ Qual 23:4537-4551

Sommer M, Fiedler S, Glatzel S, Kleber M (2004) First estimates of regional (Allgäu, Germany) and global $\mathrm{CH}_{4}$ fluxes from wet colluvial margins of closed depressions in glacial drift areas. Agric Ecosyst Environ 103:251-257

Sozanska M, Skiba U, Metcalfe S (2002) Developing an inventory of $\mathrm{N}_{2} \mathrm{O}$ emissions from British soils. Atmos Environ 36:987-998
Tilman D, Wedin D, Knops J (1996) Productivity and sustainability influenced by biodiversity in grassland ecosystems. Nature 379:718-720

Mander Ü, Uuemaa E, Kull A, Kanal A, Maddison M, Soosaar K, Salm JO, Lesta M, Hansen R, Kuller R, Harding A, Augustin J (2010) Assessment of methane and nitrous oxide fluxes in rural landscapes. Landscape Urban Plann 98:172-181

Vilain G, Garnier J, Passy P, Sivestre M, Billen G (2012) Budget of $\mathrm{N}_{2} \mathrm{O}$ emissions at the watershed scale: role of land cover and topography (the Orgeval basin, France). Biogeosciences 9:1085-1097

Vitousek PM, Mooney HA, Lubchenko J, Melillo JM (1997) Human domination of Earth's ecosystems. Science 277:494-499

Wang LX, Okin GS, D’Odorico P, Caylor KK, Macko SA (2013) Ecosystem-scale spatial heterogeneity of stable isotopes of soil nitrogen in African savannas. Landscape Ecol. doi:10.1007/s10980-012-9776-6

Wassen MJ, Barendregt A (1992) Topographic position and water chemistry of fens in the Vecht river plain, the Netherlands. J. Veg. Sc. 3:447-456

Wassen MJ, Olde Venterink H, Lapshina ED, Tanneberger F (2005) Endangered plants persist under phosphorus limitation. Nature 437:547-550

Wassen MJ, de Boer HJ, Fleischer K, Rebel KT, Dekker SC (2013) Vegetation-mediated feedbacks in water, carbon, nitrogen and phosphorus cycles. Landscape Ecol. doi: 10.1007/s10980-012-9843-Z

Wolf B, Zheng XH, Brueggemann N, Chen WW, Dannenmann M, Han XG, Sutton M, Wu HH, Yao ZS, Butterbach-Bahl $\mathrm{K}$ (2010) Grazing-induced reduction of natural nitrous oxide release from continental steppe. Nature 464:881-884

Wu J (2013) Key concepts and research topics in landscape ecology revisited: 30 years after the Allerton Park workshop. Landscape Ecol 20:1-11

Wu J, Hobbs R (2002) Key issues and research priorities in landscape ecology: an idiosyncratic synthesis. Landscape Ecol 17:355-365 